\title{
Herpes zoster ophthalmicus with trochlear nerve involvement after alcohol injection into the Gasserian ganglion
}

\author{
ROBERT J.-M. BOUGHERAT \\ The Eye Hospital, Walton Street, Oxford
}

Herpes zoster wherein the trigeminal ganglion is affected was first described by Jonathan Hutchinson ( 1869 ), but to this day many aspects of the disease are not fully understood. The virus of zoster seems to be identical with varicella virus yet the clinical manifestations differ markedly.

In the past, two types of zoster were thought to exist; idiopathic (epidemic) and symptomatic (secondary) (Duke-Elder, I965). It is not sufficiently widely appreciated that all zoster is due to reactivation of latent virus. What makes the virus replicate is still often obscure. What are the reactivating factors, and what mechanisms are involved?

In herpes zoster ophthalmicus (HZO), the nerves to the ocular muscles are occasionally

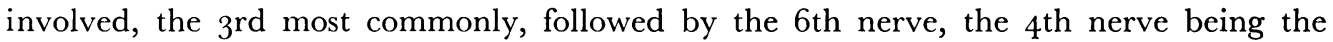
rarest (Edgerton, 1945). The factors responsible for such involvement have not been identified with any certainty.

A case is here described of a woman who developed HZO after an alcohol injection into the ipsilateral Gasserian ganglion for "tic douloureux". Subsequently the trochlear nerve on that side became involved.

The purpose of this paper is to suggest the existence of a correlation between these events and thereby to shed some light on the questions posed above.

\section{Case report}

A 72-year-old woman came to the Casualty Department complaining of pain over the right side of the face for the previous 5 days. She was mildly febrile and was vomitting.

\section{Past history}

She had had severe rheumatoid arthritis for several years and had been taking prednisolone tablets for the past 8 years. At the time of admission she was taking a maintenance dose of $7.5 \mathrm{mg}$. daily. She had contracted chicken pox at the age of 6 years. In July, 1970, she developed right-sided trigeminal neuralgia (tic douloureux) for which, on October 7, 1970, the Gasserian ganglion was injected with I ml. 90 per cent. alcohol.

\section{Examination}

The corrected visual acuity was $6 / 18$ right and $6 / 6$ left. Vesicles were present on the right side of the face in the distribution of the ophthalmic division of the right trigeminal nerve, including the naso-ciliary branch. The affected area was anaesthetic and painful (anaesthesia dolorosa). There was a pseudo-ptosis and a mucopurulent conjunctivitis. External ocular movements were full. Corneal sensation was reduced. The intraocular contents were normal. No other cranial nerves were affected at that time. 
Diagnosis

Herpes zoster ophthalmicus was diagnosed and the patient was admitted to hospital.

Investigations

Blood pressure I00/50 mm.Hg; Hb 95 per cent; R.B.C. 4,500,000 per cu.mm; W.B.C. Io,ooo per cuv $\mathrm{mm}$; erythrocyte sedimentation rate $4 \mathrm{~mm}$. Ist $\mathrm{hr}$ (Westergren). Chest and skull $x$ rays were normalo Complement fixation-test for herpes simplex was $I: 4$ and to varicella-zoster I $:$ I 28.

\section{Treatment and progress}

She was treated with dressings of 40 per cent. idoxuridine in a dimethyl-sulphoxide base (DMSO) to the affected area, and chloramphenicol ointment to the eye. She had been taking prednisolones $7 \cdot 5 \mathrm{mg}$. for the past 8 years and this dosage was continued during her illness.

Result

She made a good but slow recovery and was discharged after 2 weeks in hospital. After 7 daysi however, she complained of diplopia, and examination revealed a right superior oblique paresis (Fig. I, opposite). A repeat Hess chart 6 weeks later showed a large degree of recovery (Fig. $2 \vec{i}$ opposite).

\section{Discussion}

The clinical manifestations of herpes zoster have been said to arise idiopathically (epi demic) or symptomatically (secondary). The former is now known to be due to infections by a varicella-zoster virus. There is increasing evidence that secondary zoster represents aㅁ reactivation of a latent $\mathrm{V}-\mathrm{Z}$ virus dormant in the tissues, which has acquired neurotroplif propensities (Boyd, I958; Duke-Elder, I965; Juel-Jensen, 1970). After varicella infection. in childhood, the antibody titre to $\mathrm{V}-\mathrm{Z}$ virus falls rapidly to $\mathrm{I}: 4$ or thereabouts in post-infective phase, and it remains at this level until middle age. After this time theres is a further drop in the antibody level. As a rule shingles is a disease of the over-50s, buto the mechanism of this reactivation is not known. Many precipitating factors have been⿳亠丷⿵冂丶 suggested, such as a neoplasm (Moynihan, I 964), infection (Gelfand, I95 I), $x$-irradiation (Ellis and Stoll, I949), physical trauma (e.g. corneal foreign body), or emotional traumā (Giroire, Charbonnel, and Vercelleto, 1960; Juel-Jensen, 1970).

The mechanism of involvement of other cranial nerves is speculative. It may be thato the infection spreads from the trigeminal nerve to other motor nerves crossing the cavernoust sinus (Godtfredsen, I948; Hermann, 1962). It was suggested by Kendall (1957) that? herpes zoster is an affection of the central nervous system and not a radicular or purely $\mathrm{E}$. dorsal root ganglion affection. This would explain more logically the occasional involvement of motor nerves in the disease. But whatever the mode of spread, such spread would probably be facilitated, or even made general, by the administration of steroids (Merselis, Kaye, and Hook, 1964).

In order to demonstrate that so-called secondary herpes zoster is in fact a reactivation of latent $\mathrm{V}-\mathrm{Z}$ virus in the tissue it would be necessary to show that:

(a) The varicella virus is identical with that of herpes zoster,

(b) The patient has been infected by varicella,

(c) There had been some precipitating factor,

(d) $\mathrm{V}-\mathrm{Z}$ virus was present in the affected tissue. 



FIG. I Hess chart, showing right superior oblique palsy
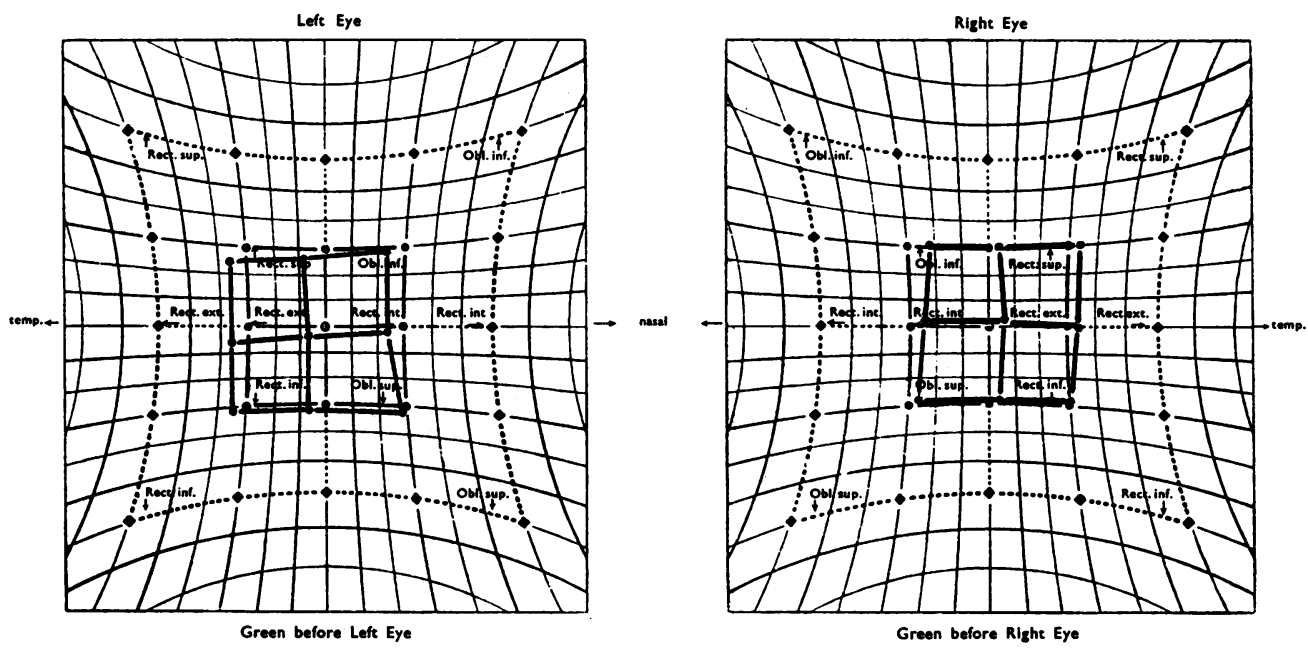

FIG. 2 Hess chart, showing marked improvement of right superior oblique palsy 6 weeks later

It is generally agreed that the viruses of varicella and zoster are immunologically and morphologically identical. Histologically the cutaneous lesions of chicken pox and shingles are very similar (Thygeson, 1956).

In this context it is interesting to recall that Bruusgaard (1932) inoculated vesicular fluid from cutaneous lesions of a herpes zoster patient into eighteen children, four of whom subsequently developed classical chicken pox and four herpes zoster.

The patient here presented had had varicella as a child. It is suggested that the alcohol injection was the precipitating factor of her zoster. It is true that a lapse of 4 weeks between injury and effect is rather long, but the exact mechanism whereby a provocation could reactivate a latent virus is not known and it could well be that the alcohol took that long to produce injurious fibrosis or necrosis in or near the ganglion.

Juel-Jensen (1970) showed that, of a series of I oo patients with herpes zoster, 65 gave a 
history suggesting a precipitating event; in $3^{8}$ per cent. this took the form of trauma to thळo part affected (Table).

Table Cause provoking zoster in 100 successive patients (from Fuel-Fensen, 1970)

\begin{tabular}{lcc}
\hline Cause & No. of cases \\
\cline { 1 - 1 } Physical trauma & $38^{*}$ \\
Frontal sinusitis & 9 \\
Malignancy & 4 \\
Ultraviolet light & 3 \\
Diabetes - no injury & 3 \\
Chemical & 2 \\
Severe emotional upset & 2 \\
Rheumatoid arthritis & 2 \\
Steroid cream rubbed into area & 2 \\
\hline All probable causes & 65 \\
No cause discovered & 35 \\
\hline
\end{tabular}

*One of these patients also had malignancy, one rheumatoid arthritis.

Evidence that $\mathrm{V}-\mathrm{Z}$ virus was present in the trigeminal ganglion in the above case is of course not available. However, Tomlinson and Esiri (I97I) were able to demonstrate⿳亠丷厂 just this in a patient with HZO who subsequently died. In their case the virus was demonstrated in both the peripheral and proximal axons of the trigeminal ganglion as well as in the ganglion itself, but it is admitted that their specimens in no way show whether $\vec{\oplus}$ the virus travelled centripetally from the skin along the axons or centrifugally from brain stem.

Involvement of ocular motor nerves is very infrequent, though no cranial nerve is exempt. Thus, in a series of 2,250 patients with herpes zoster ophthalmicus, Edgerton (1940) found forty with 6 th nerve palsy and only 21 with $4^{\text {th }}$ nerve palsy.

There is evidence to show that a localized herpes zoster may well become generalized@ under certain conditions. These include the treatment with systemic steroids or ACTH $\overrightarrow{0}$ (Merselis and others, I964), radio-mimetic drugs and $x$-irradiation (Ellis and Stoll, 1949; Hope-Simpson, 1965). It would seem that, if herpes zoster is in fact a disease of the central nervous system as suggested by Kendall (1957), large doses of steroids would facilitate a widespread dissemination of the infection, and small doses might allow a응 relatively limited spread to affect one, two or a group of cranial nerves.

\section{Conclusion}

It is suggested that in this case an alcohol injection into the Gasserian ganglion acted as a $\mathrm{O}$ precipitator in the reactivation of latent $\mathrm{V}-\mathrm{Z}$ virus, and that this was facilitated by the facto that the patient was already on systemic steroids and further that this allowed the infection to escape the confines of the trigeminal nerve to spread over and include the trochlearo nerve on the same side.

\section{Summary}

A patient is presented who had been on long-term systemic steroids and who developed herpes zoster ophthalmicus after an alcohol injection into the Gasserian ganglion. This $\stackrel{\mathcal{S}}{\stackrel{9}{+}}$ 
patient also developed a paralysis of the trochlear nerve on the same side.

A suggestion is made that these three factors are linked.

My thanks are due to Mr. Philip Awdry for permission to use his case. Dr. Juel-Jensen for kindly allowing me to publish Fig. 3, and to Mrs. MacLellan, chief orthoptist, for the Hess charts.

\section{References}

BOYD, w. (1958) "Pathology for the Physician", 6th ed., p. 737. Lea and Febiger, Philadelphia BruUsgard, e. (1932) Brit. F. Derm., 44, I

DUKE-ELDER, s. (1965) "System of Ophthalmology", vol. 8, pt. I, p. 337. Kimpton, London EDGerton, A. E. (1945) Arch. Ophthal. (Chicago), 34, 40, 114

ELlis, F., and STOLL, B. A. (1949) Brit. med. J., 2, 1323

GODTfRedSEn, E. (1948) Acta psychiat. (Kbh.), 23, 69

Gelfand, M. L. (1951) 7. Amer. med. Ass., 145, 560

GIROIRE, GHARBONNEL, and VERCELLETTO (1960) Rev. oto.-neurol.-ophthal., 32, 38

hermanN, J. s. (1962) Amer. F. Ophthal., 45, 298

hOPE-Simpson, R. E. (1965) Proc. roy. Soc. Med., 58, 9

hutchinson, J. (1869) Roy. Lond. Hosp. Rep., 6, 18 1, 263

Juel-Jensen, B. E. (1970) J. roy. Coll. gen. Practit., 20, 323

KENDALL, D. (1957) Brit. med. F., 2, 616

MERSELIS, J. G., KAYE, D., and нOок, E. W. (1964) Arch. intern. Med., 113, 679

MOYNihan, N. H. (1964) Practitioner, 192, 669

THYGESON, D. (1956) "Ocular Bacteriology and Virology". Lecture notes, Lancaster Course, p. 95

tomlinson, A., and EsIRI, M. (197I) J. Neurol. Sci. (in press) 